\title{
Analisis Potensi dan Kontribusi Pajak Reklame Dalam Meningkatkan Pendapatan Asli Daerah (PAD) Kota Palembang
}

\author{
Indah Damayanti ${ }^{1}$, Reva Maria Valianti ${ }^{2}$, Mursalin ${ }^{3}$ \\ ${ }^{1}$ Fakultas Ekonomi Universitas PGRI Palembang, indahdamayanti99917@gmail.com \\ ${ }^{2}$ Fakultas Ekonomi Universitas PGRI Palembang, revavalianti@univpgripalembang.ac.id \\ ${ }^{3}$ Fakultas Ekonomi Universitas PGRI Palembang, mursalin@univpgri-palembang.ac.id
}

\begin{abstract}
ABSTRAK
Penelitian ini bertujuan untuk mengetahui analisis potensi dan kontribusi pajak reklame dalam meningkatkan pendapatan asli daerah Kota Palembang. Jenis Penelitian ini adalah penelitian deskriptif. Penelitian ini dilakukan di Badan Pengelolaan Pajak Daerah Kota Palembang. Variabel dalam penelitian ini adalah potensi dan kontribusi pajak reklame. Data yang digunakan adalah data sekunder dengan teknik pengumpulan data menggunakan jenis studi kepustakaan dan dokumentasi. Berdasarkan hasil penelitian yang telah dilakukan terhadap seluruh data yang diperoleh di Badan Pengelolaan Pajak Daerah Kota Palembang, dapat diambil beberapa kesimpulan antara lain penerimaan pajak reklame di Kota Palembang memiliki potensi yang cukup besar terhadap Pendapatan Asli Daerah Kota Palembang, potensi penerimaan pajak reklame pada tahun 2020 adalah sebesar $\mathrm{Rp}$ 21.290.052.939. Kontribusi yang diberikan pajak reklame terhadap Pendapatan Asli Daerah Kota Palembang masih tergolong "sangat kurang" karena rasio kontribusi yang diberikan pada tahun 2016 sampai tahun 2019 rata-rata kurang dari 10\%. Upaya-upaya untuk meningkatkan penerimaan pajak reklame terhadap Pendapatan Asli Daerah Kota Palembang dengan melakukan pendataan secara rutin terhadap objek pajak reklame yang baru dan yang sudah ada, serta melakukan penyuluhan/sosialisasi kepada Wajib Pajak agar melaksanakan kewajiban perpajakannya dengan baik dan benar.
\end{abstract}

Kata Kunci : Potensi, Kontribusi, Pajak Reklame, Pendapatan Asli Daerah

\begin{abstract}
This study aims to determine the analysis of the potential and contribution of advertisement tax in increasing the original income of Palembang City. This type of research is descriptive research. This research was conducted at the Regional Tax Management Agency of Palembang City. The variable in this study is the potential and contribution of advertisement tax. The data used are secondary data with data collection techniques using the type of study of literature and documentation.Based on the results of research conducted on all data obtained at the Palembang City Regional Tax Management Agency, several conclusions can be drawn including advertisement tax revenue in the city of Palembang having considerable potential towards the Original Revenue of the City of Palembang, the potential for advertisement tax revenue in 2020 is Rp.21,290,052,939. The contribution of advertisement tax to Palembang's Original Local Revenue is still classified as "very less" because the ratio of contributions made in 2016 to 2019 is on average less than 10\%. Efforts to increase the advertisement tax revenue of Palembang's Original Local Revenue by routinely collecting data on new and existing advertisement tax objects, and conducting counseling / socialization to taxpayers to carry out their tax obligations properly and correctly.
\end{abstract}

Keywords : Potential, Contributions, Advertisement Tax, Local Revenue

\section{A. PENDAHULUAN}

Indonesia merupakan negara yang menganut sistem otonomi daerah dengan menjalankan tugas dan wewenang pemerintahannya . Otonomi daerah merupakan salah satu wujud reformasi terhadap penyelenggaraan pemerintah daerah Provinsi/Kabupaten/Kota guna mengantisipasi berbagai tuntutan perubahan ketatanegaraan tersebut dalam menghadapi tantangan persaingan global baik di 
dalam maupun luar negeri yang tercantum dalam Undang-undang No. 32 tahun 2004 tentang Pemerintah Daerah.

Adanya otonomi daerah di Indonesia, menuntut setiap daerah atau Kota mampu merencanakan sumber pendapatan tiap daerah maupun Kota, mempersiapkan sumber daya manusia yang baik, sumber keuangan yang cukup serta sarana dan prasarana yang memadai dalam pelaksanaannya. Pelaksanaan otonomi daerah memberikan kewenangan kepada daerah untuk mengatur dan mengelola rumah tangga daerahnya masing-masing guna mendukung kemajuan pemerintahan.

Pemerintah yaitu sebagai penggerak sekaligus pendorong, masing-masing daerah tersebut yang harus bertindak lebih efektif dan efisien secara optimal agar pengelolaan daerahnya lebih terfokus dan mencapai sasaran yang telah ditentukan. Pemerintah daerah harus mencari sumber-sumber lainnya yang ada di daerah masing-masing untuk diandalkan sebagai tulang punggung Pendapatan Asli Daerah (PAD).

Pemerintah daerah wajib aktif menggali potensi keuangannya, baik melalui intensifikasi yaitu dengan pemanfaatan secara optimal sumber pendapatan daerah maupun melalui ekstensifikasi objek pendapatan daerahnya, untuk memenuhi kebutuhan pembiayaan pemerintah dan pembangunan didaerahnya melalui Pendapatan Asli Daerah (PAD). Untuk meningkatkan akuntabilitas dan keleluasaan dalam pengelolaan keuangan daerah diwujudkan dalam bentuk penetapan Anggaran Pendapatan dan Biaya Daerah (APBD) sesuai dengan kebutuhan dan aspirasi masing-masing daerah. Sumber-sumber penerimaan daerah yang potensial harus digali secara maksimal di dalam peraturan perundang-undangan yang berlaku, termasuk diantaranya merupakan pajak daerah dan retribusi daerah yang sejak lama sudah menjadi salah satu unsur PAD yang utama. Semakin tinggi kewenangan keuangan yang dimiliki masing-masing daerah, maka semakin tinggi peranan PAD dalam struktur keuangan daerahnya. Salah satu sumber PAD dalam APBD adalah pajak daerah.

Secara umum pajak adalah pungutan paksa yang dilakukan oleh pemerintah terhadap Wajib Pajak dengan membayar iuran wajib kepada Negara berdasarkan undang-undang. Ciri khas pajak dibanding dengan jenis pungutan lainnya adalah Wajib Pajak (Tax Payer) tidak menerima jasa timbal balik yang dapat ditunjuk secara langsung dari pemerintah. Di Indonesia pemungutan pajak menggunakan sistem pemungutan pajak Self Assessment System, yaitu suatu sistem pemungutan pajak yang memberikan wewenang kepercayaan, dan tanggung jawab kepada Wajib Pajak untuk menghitung, membayar dan melaporkan sendiri besarnya pajak yang harus dibayar dan aparat pajak (fiskus) hanya bertugas melakukan penyuluhan, pembinaan, pengawasan dan pemeriksaan terhadap kewajiban perpajakannya. Dengan sistem ini pelaksanaan administrasi perpajakan diharapkan dapat mempermudah dalam pelaksanaan, tertib dan terkendali.

Berdasarkan Undang-Undang Nomor 28 Tahun 2009, Pajak Daerah dan Retribusi Daerah terbagi menjadi dua yaitu Pajak Provinsi dan Pajak Kabupaten/Kota. Menurut pasal 1 Undang-Undang Nomor 28 Tahun 2009 menyatakan bahwa : "Pajak daerah yang disebut pajak adalah kontribusi wajib kepada daerah yang terutang oleh orang pribadi atau badan yang bersifat memaksa berdasarkan Undang-Undang dengan tidak mendapatkan imbalan secara langsung dan digunakan untuk keperluan daerah bagi sebesar-besarnya kemakmuran rakyat." Dengan adanya peraturan daerah tentang pengenaan pemungutan pajak 
memberikan peluang kepada daerah Kabupaten/Kota untuk memungut jenis pajak daerah lain yang dipandang memenuhi syarat. Pendapatan jenis pajak lainnya harus benar-benar bersifat spesifik dan potensial di daerah.

Berdasarkan pengertian di atas dimaksudkan untuk memberikan keleluasaan kepada daerah Kabupaten/Kota dalam mengantisipsi situasi dan kondisi serta perkembangan perekonomian daerah pada masa yang akan mendatang. Pemungutan pajak daerah yang dilakukan oleh pemerintah Kabupaten/Kota kepada masyarakat juga bertujuan untuk membiayai penyelenggaraan tugas-tugas pemerintah, pembangunan dan pembinaan kemasyarakatan secara berdayaguna dan berhasil dalam upaya meningkatkan taraf hidup bagi masyarakat.

Di Kota Palembang pajak daerah merupakan sumber penerimaan yang berpotensi. Salah satunya pemungutan pajak reklame yang berupa pemungutan melalui semua kegiatan mengenai penyelenggaraan reklame baik didalam maupun di luar gedung. Pajak reklame merupakan bagian dari Pajak Daerah yang diatur dalam peraturan daerah Nomor 28 Tahun 2009 yang menyatakan bahwa Wajib Pajak orang pribadi atau badan yang menurut peraturan perundang-undangan pajak diwajibkan untuk melakukan pembayaran pajak. Objek pajak reklame adalah semua penyelenggara reklame. Sedangkan reklame adalah benda, alat, perbuatan, atau media yang bentuk dan corak yang ragamnya dirancang untuk tujuan komersial memperkenalkan, menganjurkan, mempromosikan, atau untuk menarik perhatian umum terhadap barang, jasa, orang, atau badan, yang dapat dilihat, dibaca, didengar, dirasakan, dan/atau dinikmati oleh umum.

Mengingat pentingnya pajak daerah sebagai sumber Pendapatan Asli Daerah (PAD), maka Pemerintah Kota Palembang berusaha memungut pajak daerah secara profesional dan transparan berdasarkan peraturan Perundang-Undangan yang telah ditetapkan serta dapat mencapai target realisasi penerimaan pajak daerah yang telah ditetapkan dalam rangka optimalisasi dan usaha meningkatkan kontribusinya terhadap Anggaran Pendapatan dan Belanja Daerah (APBD).

Badan Pengelolaan Pajak Daerah (BPPD) adalah suatu instansi yang bertujuan untuk mengumpulkan penerimaan Pendapatan Asli Daerah (PAD) yang bersumber dari pajak daerah dan retribusi daerah dan pajak lainnya untuk pembangunan daerah. Agar terwujudnya keinginan tersebut, supaya pengelolaan pendapatan asli daerah dapat dilaksanakan dengan baik serta berhasil, maka dengan keputusan Peraturan Daerah Kota Palembang Nomor 14 Tahun 2010 tentang pajak reklame, serta peraturan Walikota Palembang Nomor 18 Tahun 2011 tentang Persyaratan, Mekanisme dan Prosedur Tetap Pemungutan Pajak Reklame.

Target dan realisasi Pajak Reklame dan Pendapatan Asli Daerah pada tahun 2016 sampai dengan tahun 2019 berdasarkan sumber dari Badan Pengelolaan Pajak Daerah Kota Palembang dapat dilihat pada tabel di bawah ini :

Tabel Target dan Realisasi Pajak Reklame Kota Palembang Periode Tahun 2016-2019

\begin{tabular}{|c|c|c|c|}
\hline Tahun & $\begin{array}{c}\text { Target Pajak Reklame } \\
\text { (Rp) }\end{array}$ & $\begin{array}{c}\text { Realisasi Pajak Reklame } \\
\text { (Rp) }\end{array}$ & $\%$ \\
\hline 2016 & 15.604 .719 .571 & 16.567 .211 .469 & 106,17 \\
\hline 2017 & 17.605 .000 .000 & 18.113 .700 .816 & 102,89 \\
\hline 2018 & 19.200 .000 .000 & 17.641 .773 .173 & 91,88 \\
\hline 2019 & 20.000 .000 .000 & 20.084 .955 .603 & 100,42 \\
\hline
\end{tabular}

Sumber : Badan Pengelolaan Pajak Daerah (BPPD) Palembang, 2020. 
Tabel Target dan Realiasi Pendapatan Asli Daerah Kota Palembang Periode Tahun 2016-2019

\begin{tabular}{|c|c|c|c|}
\hline Tahun & $\begin{array}{c}\text { Target Pendapatan } \\
\text { Asli Daerah (Rp) }\end{array}$ & $\begin{array}{c}\text { Realisasi Pendapatan } \\
\text { Asli Daerah (Rp) }\end{array}$ & $\%$ \\
\hline 2016 & 840.572 .306 .099 & 781.346 .935 .715 & 92,95 \\
\hline 2017 & 1.099 .308 .967 .841 & 1.091 .704 .605 .854 & 99.31 \\
\hline 2018 & 1.100 .505 .155 .700 & 953.257 .612 .127 & 86,62 \\
\hline 2019 & 1.657 .808 .205 .237 & 1.081 .514 .950 .141 & 65,24 \\
\hline
\end{tabular}

Sumber: Badan Pengelolaan Pajak Daerah (BPPD) Palembang, 2020.

Berdasarkan data di atas, realisasi pajak reklame dari tahun 2016 hingga 2019 memiliki potensi yang baik bagi Pendapatan Asli Daerah (PAD) Kota Palembang. Namun dari data di atas, Realisasi Pendapatan Asli daerah (PAD) dari tahun 2016 hingga tahun 2019 kurang baik. Sehingga dapat dikatakan kurangnya kontribusi yang baik bagi Pendapatan Asli Derah (PAD) Kota Palembang. Upaya peningkatan penerimaan pajak reklame dari tahun ke tahun diharapkan mampu memberikan kontribusi serta pengaruh yang baik bagi perkembangan pembangunan serta mampu meningkatkan PAD Kota Palembang.

\section{B. KAJIAN TEORI}

\section{Definisi Pajak}

Definisi Pajak menurut Undang-Undang Nomor 16 tahun 2009 tentang Perubahan Keempat atas Undang-Undang Nomor 6 tahun 1983 tentang Ketentuan Umum dan Tata Cara Perpajakan pada Pasal 1 Ayat 1 berbunyi "Pajak adalah kontribusi wajib kepada negara yang terhutang oleh orang pribadi atau badan yang bersifat memaksa berdasarkan undang-undang, dengan tidak mendapatkan imbalan secara langsung dan digunakan untuk keperluan negara bagi sebesar-besarnya kemakmuran rakyat."

Menurut Mardiasmo (2018:3), pajak adalah iuran rakyat kepada kas negara berdasarkan undang-undang (yang dapat dipaksakan) dengan tidak mendapatkan jasa timbal (kontraprestasi) yang langsung dapat ditunjukan dan yang digunakan untuk membayar pengeluaran umum.

\section{Fungsi Pajak}

Menurut Mardiasmo (2018:4), ada dua fungsi pajak yaitu :

1. Fungsi Anggaran (Budgetair)

Pajak berfungsi sebagai salah satu sumber dana bagi pemerintah untuk membiayai pengeluaranya.

2. Fungsi Mengatur (Regulerend)

Pajak berfungsi sebagai alat untuk mengatur atau melaksanakan kebijaksanaan pemerintah dalam bidang sosial dan ekonomi

\section{Pengelompokan Pajak}

Menurut Mardiasmo (2018:7), terdapat tiga pengelompokan pajak yaitu :

1) Menurut Penggolongannya

$>$ Pajak Langsung, yaitu pajak yang harus dipikul sendiri oleh Wajib Pajak dan tidak dapat di limpahkan kepada orang lain.

> Pajak Tidak Langsung, yaitu pajak yang pada akhirnya dapat dibebankan atau dilimpahkan kepada orang lain. 
2) Menurut Sifatnya

> Pajak Subjektif, yaitu pajak yang berpangkal atau berdasarkan pada subjeknya, dalam arti memerhatikan keadaan diri Wajib Pajak

> Pajak Objektif, yaitu pajak yang berpangkal pada objeknya, tanpa memperhatikan keadaan diri Wajib Pajak.

3) Menurut Lembaga Pemungutnya

> Pajak Pusat, yaitu pajak yang dipungut oleh pemerintah pusat dan digunakan untuk membiayai rumah tangga Negara. Contoh : Pajak Penghasilan, Pajak Nilai dan Pajak Penjualan atas Barang Mewah dan Bea Materai.

> Pajak Daerah, yaitu pajak yang dipungut oleh Pemerintah Daerah dan digunakan untuk membiayai rumah tangga daerah. Pajak daerah terdiri atas:

$\checkmark$ Pajak Provinsi

$\checkmark$ Pajak Kabupaten/Kota

\section{Pajak Reklame}

Pajak reklame adalah pajak atas penyelenggaraan reklame. Sedangkan reklame itu sendiri adalah benda, alat, perbuatan, atau media yang di bentuk dan corak ragamnya dirancang untuk tujuan komersil memperkenalkan, menganjurkan, mempromosikan, atau untuk menarik perhatian umum terhadap barang, jasa, orang, atau badan, yang dapat dilihat, dibaca, didengar, dirasakan, dan/atau dinikmati oleh umum. (Perda Kota Palembang No. 14 Tahun 2010 pasal 1).

\section{Subjek dan Wajib Pajak Reklame}

Subjek Pajak reklame adalah orang pribadi atau badan yang menggunakan reklame. Wajib Pajak reklame adalah orang pribadi atau badan yang menyelenggarakan reklame. (Perda Kota Palembang No. 14 Tahun 2010 pasal 3).

\section{Objek Pajak Reklame}

Objek Pajak reklame adalah semua penyelenggara reklame. Penyelenggara reklame dapat dilakukan oleh penyelenggara reklame atau perusahaan jasa periklanan yang terdaftar pada badan pengelola pajak daerah (Perda Kota Palembang No.14 Tahun 2010 pasal 2). Dibawah ini yang termasuk objek pajak reklame :

1) Reklame papan/ billboard/videotron/megatron/ Large Electronic Display (LED) dan sejenisnya

2) Reklame kain

3) Reklame melekat, stiker

4) Reklame selebaran

5) Reklame berjalan, termasuk pada kendaraan

6) Reklame udara

7) Reklame apung

8) Reklame suara

9) Reklame film (slide)

10) Reklame peragaan

\section{Dasar Hukum Pengenaan Pajak Reklame}

Pemungutan pajak reklame di Indonesia saat ini didasarkan pada dasar hukum yang jelas dan kuat sehingga harus dipatuhi oleh masyarakat dan pihak yang terkait. Dasar hukum pemungutan pajak reklame di Kota Palembang adalah sebagai berikut: 
1) Undang-Undang Nomor 28 tahun 2009 tentang Pajak Daerah dan Retribusi Daerah.

2) Undang-Undang Nomor 34 tahun 2000 yang merupakan perubahan atas Undang-Undang Nomor 18 tahun 1997 tentang Pajak Daerah dan Retribusi Daerah.

3) Peraturan Daerah Kota Palembang Nomor 14 Tahun 2010 tentang Pajak Reklame.

4) Peraturan Walikota Palembang Nomor 18 Tahun 2011 tentang Persyaratan, Mekanisme dan Prosedur Tetap Pemungutan Pajak Reklame.

\section{Dasar Pengenaan Pajak Reklame}

Dasar pengenaan pajak reklame adalah Nilai Sewa Reklame (Perda Kota Palembang No. 14 Tahun 2010 pasal 4) Nilai Sewa Reklame (NSR) adalah nilai yang ditetapkan sebagai dasar perhitungan penetapan besarnya pajak reklame. Nilai Sewa Reklame ditentukan melalui Nilai Jual Objek Reklame (NJOR) dan Nilai Strategis Pemasangan Reklame (NSPR). Perhitungan Nilai Sewa Reklame (NSR) ditetapkan dengan Peraturan Daerah. Peraturan Daerah menetapkan bahwa NSR ditetapkan oleh Bupati/Walikota dengan persetujuan DPRD Kabupaten/Kota yang bersangkutan dengan mengacu pada Keputusan Menteri Dalam Negeri.

\section{$N S R=N J O R+N S P R$ \\ - NSR = Nilai Sewa Reklame \\ - NJOR = Nilai Jual Objek Reklame \\ - NSPR = Nilai Sewa Pajak Reklame}

Apabila Reklame diselenggarakan oleh pihak ketiga, nilai Sewa Reklame tersebut ditetapkan berdasarkan nilai kontrak reklame. Apabila reklame diselenggarakan sendiri maka Nilai Sewa Reklame dihitung dengan memperhatikan faktor jenis, bahan yang digunakan, lokasi penempatan, waktu, jangka waktu penyelenggaraan, jumlah, dan ukuran media reklame.

\section{Tarif Pajak Reklame}

Pajak reklame yang terutang dipungut diwilayah daerah tempat reklame tersebut diselenggarakan. Berdasarkan Peraturan Walikota Palembang Nomor 18 tahun 2011 Pasal 7 tarif pajak reklame ditetapkan sebesar 25\% (dua puluh lima persen). Adapun rumus untuk menghitung pajak reklame sebagai berikut:

\section{Pajak Reklame $=25 \%$ x Nilai Sewa Reklame}

\section{Sistem Pemungutan Pajak reklame}

Pada Peraturan Walikota Palembang Nomor 18 Tahun 2011 pasal 27 sistem pemungutan pajak reklame di Indonesia ada 2 cara:

1) Sistem Menghitung Sendiri (Self Assesment System)

2) Sistem Ketetapan (Official Assesment System)

\section{Potensi Pajak Reklame}

Potensi adalah kemampuan yang mempunyai kemungkinan untuk dikembangkan, kekuatan dan kesanggupan (Suharso dan Retnoningsih, 2015: 388). Pengertian di atas dapat disimpulkan bahwa segala kemampuan yang dimiliki pajak reklame untuk menjadi sumber penerimaan bagi suatu daerah dan jumlah maksimum penerimaan pajak yang bisa meningkatkan pada titik tertentu, sehingga 
pajak reklame dapat pula dikatakan target penerimaan pajak reklame yang telah ditetapkan oleh Dinas Pendapatan Pajak Daerah.

Analisis potensi ini bermanfaat bagi manajemen pemerintah daerah untuk memberikan pertimbangan tentang potensi penerimaan yang masih dapat digali dan potensi keuntungan berinvestasi. Semakin besar proporsi pajak reklame, maka semakin layak pajak reklame untuk diupayakan peningkatannya dimasa yang akan datang. Sebaliknya semakin kecil proporsi pajak reklame, maka upaya identifikasi mengenai kelayakan untuk dijadikan sumber penerimaan di masa datang perlu diintensifikasi (Pekei, 2016: 131). Nilai-nilai yang menjadi potensi pajak reklame dalam meningkatkan Pendapatan Asli Daerah adalah sebagai berikut :

\section{Nilai Strategis Kawasan}

Kawasan reklame adalah batasan wilayah tertentu sesuai dengan pemanfaatan wilayah tersebut yang dapat digunakan untuk pemasangan reklame. Nilai strategis lokasi reklame adalah ukuran nilai yang ditetapkan pada titik lokasi pemasangan reklame tersebut berdasarkan kriteria kepadatan pemanfaatan tata ruang. Kota untuk berbagai aspek kegiatan dibidang usaha. Nilai jual objek reklame adalah keseluruhan pembayaran/pengeluaran biaya yang dikeluarkan oleh pemilik dan atau penyelenggaraan reklame termasuk dalam hal ini adalah biaya/harga beli bahan reklame, konstruksi, instalasi listrik, pembayaran/ongkos perakitan, pemancaran, peragaan, penayangan, pengecatan, pemasangan dan transportasi pengangkutan, dan hal-hal lain sebagainya sampai dengan bangunan reklame rampung, dipancarkan diperagakan, ditayangkan dan atau terpasangnya ditempat yang telah ditetapkan (Perda Kota Palembang Nomor 14 Tahun 2010).

\section{Analisis Potensi Pajak Reklame}

Berdasarkan Keputusan Kepala Dinas Pelayanan Pajak Nomor 376 Tahun 2013 tentang Penetapan Formula Baku Perhitungan Potensi dan Rencana Penerimaan bahwasannya rumus untuk menghitung besarnya potensi pajak reklame di tahun yang akan datang dapat diketahui dengan cara menganalisis realisasi ketetapan tahun lalu ditambah dengan prosentase rata-rata kenaikan pertahun dikalikan realisasi ketetapan tahun lalu. Rumus potensi pajak reklame adalah :

Potensi pajak reklame $=$ Jumlah realisasi ketetapan tahun lalu +

(prosentase rata-rata kenaikan per tahun $\mathrm{x}$ realisasi ketetapan tahun lalu)

\section{Kontribusi Pajak Reklame}

Kontribusi adalah uang iuran kepada perkumpulan dan sebagainya (Suharso dan Ana Retnoningsih, 2015:264). Dalam Bahasa Inggris yaitu contribution yang artinya adalah menerima atau mengumpulkan sumbangan (John dan Hassan, 2007: 144). Kontribusi dapat berupa materi atau suatu tindakan. Perhitungan kontribusi pajak reklame terhadap Pendapatan Asli Daerah sebagai berikut:

$$
\text { Kontribusi Pajak Reklame }=\frac{\text { Jumlah Realisasi Pajak Reklame }}{\text { Jumlah Realisasi PAD }} \times 100 \%
$$

\section{Pendapatan Asli Daerah}

Secara garis besar Pendapatan Asli Daerah (PAD) yaitu hasil yang diperoleh dari Pemerintah Pusat yang dapat diukur dengan uang karena wewenangnya diberikan kepada masyarakat yang berupa hasil Pajak Daerah dan Retribusi Daerah, 
hasil Perusahaan Milik Daerah dan pengelolaan kekayaan daerah serta pendapatan daerah lain-lain yang sah.

Undang-Undang Nomor 33 Tahun 2004 tentang Perimbangan Keuangan Antara Pemerintah Pusat dan Daerah pada pasal 6 tentang Pendapatan Asli Daerah, Pendapatan dapat dikelompokan menjadi:

a. Pendapatan Asli Daerah yang selanjutnya disebut PAD, yaitu :

1) Pajak daerah

2) Retribusi daerah

3) Hasil penjualan kekayaan daerah yang dipisahkan

4) Lain-lain PAD yang sah

b. Dana perimbangan, dan

c. Lain-lain pendapatan daerah yang sah Pendapatan Asli Daerah yang sah yang meliputi:

a. Hasil penjualan kekayaan daerah yang tidak dipisahkan

b. Jasa giro

c. Pendapatan bunga

d. Keuntungan selisih nilai tukar rupiah terhadap mata uang asing dan

e. Komisi, potongan, ataupun bentuk lain sebagai akibat dari penjualan dan atau pengadaan barang dan atau jasa oleh daerah.

\section{METODE PENELITIAN}

Metode penelitian kualitatif adalah penelitian tentang riset yang bersifat deskriptif dan cenderung menggunakan analisis (Sugiyono, 2013:7) sedangkan metode yang di gunakan dalam penelitian ini adalah metode penelitian kualitatif. Penelitian ini bersifat deskriptif kualitatif, artinya penelitian ini di tunjukan untuk menggambarkan bukan berdasarkan perhitungan statistika melainkan hasil observasi, dokumentasi pribadi dan dokumen lainnya.

\section{1) Variabel dan Definisi Operasional Variabel}

Pengertian variabel penelitian menurut Sugiyono (2017:38) adalah suatu atribut atau sifat atau nilai dari orang, obyek, organisasi atau kegiatan yang mempunyai variasi tertentu yang ditetapkan oleh peneliti untuk dipelajari dan kemudian ditarik kesimpulan. berikut:

Operasional variabel yang digunakan dalam penelitian ini adalah sebagai

Tabel Definisi Operasional Variabel

\begin{tabular}{|c|c|c|c|}
\hline No. & Variabel & Definisi & Indikator \\
\hline 1. & $\begin{array}{l}\text { Potensi Pajak } \\
\text { Reklame dalam } \\
\text { Meningkatkan PAD }\end{array}$ & $\begin{array}{l}\text { Kemampuan yang mempunyai } \\
\text { kemungkinan untuk di kembangkan, } \\
\text { kekuatan dan kesanggupan (Suharso } \\
\text { dan Retnoningsih, 2015: 388). }\end{array}$ & 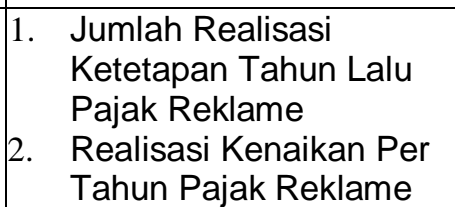 \\
\hline 2. & $\begin{array}{l}\text { Kontribusi Pajak } \\
\text { Reklame dalam } \\
\text { Meningkatkan PAD }\end{array}$ & $\begin{array}{l}\text { Uang iuran kepada perkumpulan dan } \\
\text { sebagainya (Suharso dan } \\
\text { Retnoningsih, 2015: 264). }\end{array}$ & $\begin{array}{l}\text { 1. Jumlah Realisasi Pajak } \\
\text { Reklame } \\
\text { 2. Jumlah Realisasi } \\
\text { Pendapatan Asli Daerah }\end{array}$ \\
\hline
\end{tabular}

\section{2) Populasi dan Sampel}

$>$ Populasi Penelitian

Populasi penelitian menurut Sugiyono (2013:115) adalah wilayah generalisasi yang terdiri dari objek/subjek yang mempunyai kuantitas dan karakteristik 
tertentu yang diterapkan oleh peneliti untuk mempelajari dan kemudian ditarik kesimpulannya.

Populasi dalam penelitian ini adalah Pajak Reklame dan Pendapatan Asli Daerah Kota Palembang.

$>$ Sampel Penelitian

Sampel penelitian menurut Sugiyono (2013:217) adalah bagian dari jumlah dan karakteristik yang dimiliki oleh populasi. Pengukuran sampel merupakan suatu langkah untuk menentukan besarnya sampel yang diambil dalam melaksanakan penelitian.

Pengambilan sampel ini harus dilakukan sedemikian rupa sehingga diperoleh sampel yang benar-benar dapat menggambarkan populasi yang sebenarnya atau representative (mewakili). Sampel yang digunakan dalam penelitian ini adalah Pajak Reklame dan Pendapatan Asli Daerah (PAD) Kota Palembang tahun 2016-2019

\section{3) Sumber Data}

Menurut Sugiyono (2013 : 225) sumber data penelitian pada dasarnya dapat dikelompokan menjadi dua yaitu :

a) Data Primer

Data primer yaitu sumber data yang di peroleh secara langsung dari objek yang diteliti.

b) Data Sekunder

Data sekunder yaitu sumber data yang tidak langsung memberikan data kepada pengumpul data, misalnya lewat orang lain atau lewat dokumen yang sudah ada.

Data yang digunakan dalam penelitian ini adalah data sekunder. .

\section{4) Teknik Pengumpulan Data}

Teknik pengumpulan data adalah langkah yang paling strategis dalam penelitian, karena tujuan utama dari penelitian adalah mendapatkan data (Sugiyono,2013: 224)

Jenis-jenis teknik pengumpulan data dalam penelitian ini adalah :

a) Studi Kepustakaan

Dilakukan dengan mengumpulkan buku-buku maupun sumber bacaan sebagai referensi yang digunakan untuk acuan yang berhubungan dengan permasalahan yang akan di bahas untuk memperoleh pemahaman atas masalah yang ada dalam penelitian ini.

b) Dokumentasi

Mengumpulkan data dengan mengumpulkan informasi yang tersedia dan laporan-laporan yang mendukung penelitian ini dengan data yang sudah ada sebelumnya. Data yang dimaksud berupa data Pajak Reklame dan PAD Kota Palembang.

\section{5) Teknik Analisis Data}

Menurut Sugiyono (2017:13-14), teknik analisis data dalam penelitian dibagi menjadi dua yaitu :

a) Analisis Kualitatif

Analisis kualitatif adalah suatu metode analisis dengan menggunakan yang berbentuk kata, kalimat, skema, dan gambar. 
b) Analisis Kuantitatif

Analisis kuantitatif adalah suatu metode penelitian dengan menggunakan data berbentuk angka atau kualitatif yang di angkakan.

Teknik analisis data yang digunakan dalam penelitian ini adalah analisis kualitatif.

Penelitian ini dilakukan dengan menerapkan konsep perhitungan rasio potensi dan rasio kontribusi pajak reklame dengan menghitung kedua rasio dari target pajak reklame dan target realisasi pendapatan asli daerah Kota Palembang dengan rumus:

a) Rasio Potensi Pajak Reklame

Berdasarkan keputusan Kepala Dinas Pelayanan Pajak Nomor 376 Tahun 2013 Tentang Penetapan Formula Baku Perhitungan Potensi Pajak Reklame dengan rumus :

Potensi pajak reklame $=$ Jumlah realisasi ketetapan tahun lalu + (prosentase rata-rata kenaikan per tahun $\mathrm{x}$ realisasi ketetapan tahun lalu)

b) Rasio Kontribusi Pajak Reklame

Perhitungan kontribusi pajak reklame terhadap Pendapatan Asli Daerah sebagai berikut:

Kontribusi Pajak Reklame $=\frac{\text { Jumlah Realisasi Pajak Reklame }}{\text { Jumlah Realisasi PAD }} \times 100 \%$

\section{HASIL PENELITIAN DAN PEMBAHASAN}

Pajak merupakan sumber penerimaan dari masyarakat untuk negara yang pasti dan mencerminkan kegotong-royongan masyarakat dalam membiayai negara untuk perkembangan negaranya. BPPD pun berusaha memaksimalkan penerimaan pajak daerah yang salah satunya berkerja dari sektor pajak reklame. Hasil pencapaian ini sangat berdampak pada pendapatan pajak reklame. Pendapatan Asli Daerah Kota Palembang yang dimana BPPD adalah badan yang memungut pajak daerah. Survei pendahuluan penulis mengenai potensi dan kontribusi pajak reklame bahwasanya terdapat beberapa masalah yang timbul pada penerimaan pajak reklame yang berdampak pada tingkat pendapatan pajak reklame.

Berdasarkan hal tersebut penulis menganalisis dari teori-teori yang dianggap sesuai dengan permasalahan yang ada. Pada bab ini penulis akan menganalisis variabel potensi pajak dengan indikator jumlah realisasi ketetapan tahun lalu pajak reklame dan realisasi kenaikan per tahun pajak reklame, variabel yang kedua yaitu kontribusi pajak reklame dengan indikator berupa jumlah realisasi pajak reklame dan jumlah realisasi pendapatan asli daerah.

\section{Analisis Potensi Pajak Reklame dalam Mengingkatkan Pendapatan Asli Daerah}

Analisis potensi pajak reklame dimaksud untuk mengetahui kemampuan Kota Palembang dalam menghasilkan penerimaan pajak reklame dengan anggapan Wajib Pajak (WP) reklame menaati dan membayar pajaknya sesuai dengan potensi yang dimiliki. Pajak reklame merupakan salah satu sektor sumber dari penerimaan Pendapatan Asli Daerah Kota Palembang. Adapun analisis dari potensi pajak reklame adalah Nilai Strategis Kawasan

Berdasarkan teori yang diterapkan potensi pajak reklame dengan nilai strategis adalah bahwa jenis reklame, tarif reklame dan kawasan pajak reklame sendiri diatur dalam Peraturan Daerah Kota Palembang Nomor 14 Tahun 2010 dan Undang- 
Undang Nomor 28 tahun 2009 dan potensi pajak reklame berdasarkan kawasan bernilai strategis adalah sebagai berikut :

Penyelenggaraan atau pendirian reklame harus dilakukan ditempat-tempat yang dianggap memiliki nilai jual yang akan berpengaruh juga pada produk/jasa yang akan ditawarkan melalui pemasangan iklan pada reklame. Jenis reklame yang digunakan dan akan mempunyai nilai pajak biasanya didirikan di atas gedung, di atas tanah, diatas air dan sebagainya. Tarif-tarif pengenaan pajak reklame biasanya ditetapkan berdasarkan dimana reklame tersebut dipasang, bila tempat tersebut berada ditengah Kota dan jalan pusat Kota maka tarif yang digunakan adalah tarif khusus yang dimana tarif tersebut akan dikalikan dengan luas ukuran reklame yang hasilnya terdapat NPP (nilai pokok pajak) yang mempunyai sumbangan besar untuk di setorkan pada kas daerah yang artinya NPP (nilai pokok pajak) tersebut akan membantu meningkatkan Pendapatan Asli Daerah Kota Palembang

Berdasarkan keputusan Kepala Dinas Pelayanan Pajak Nomor 376 Tahun 2013 Tentang Penetapan Formula Baku Perhitungan Potensi Pajak Reklame dengan rumus :

Potensi pajak reklame $=$ Jumlah realisasi ketetapan tahun lalu + (prosentase rata-rata kenaikan per tahun $\mathrm{x}$ realisasi ketetapan tahun lalu)

Adapun langkah-langkah untuk menghitung kenaikan realisasi pajak reklame tiap tahunnya adalah sebagai berikut :

Tabel Realisasi Pajak Reklame Kota Palembang

\begin{tabular}{|c|c|c|}
\hline No. & Tahun & Realisasi Pajak Reklame (Rp) \\
\hline 1. & 2016 & 16.567 .211 .469 \\
\hline 2. & 2017 & 18.113 .700 .816 \\
\hline 3. & 2018 & 17.641 .773 .173 \\
\hline 4. & 2019 & 20.084 .955 .603 \\
\hline
\end{tabular}

Sumber : Badan Pengelolaan Pajak Daerah (BPPD) Palembang, 2020

Tahun $2017=\frac{18.113 .700 .816-16.567 .211 .469}{18.113 .700 .816} \times 100=8,54 \%$

Tahun $2018=\frac{17.641 .773 .173-18.113 .700 .816}{17.641 .773 .173} \times 100=-2,68 \%$

Tahun $2019=\frac{20.084 .955 .603-17.641 .773 .173}{20.084 .955 .603} \times 100 \%=12 \%$

Tabel Tingkat Prosentase Realisasi Kenaikan Per Tahun
Pajak Reklame Kota Palembang
\begin{tabular}{|c|r|r|}
\hline Tahun & Realisasi Pajak Reklame (Rp) & Tingkat (\%) \\
\hline $2016 / 2017$ & 18.113 .700 .816 & 8,54 \\
\hline $2017 / 2018$ & 17.641 .773 .173 & $-2,68$ \\
\hline $2018 / 2019$ & 20.084 .955 .603 & 12 \\
\hline
\end{tabular}

Sumber: Penulis, 2020.

Tabel diatas dapat terlihat tingkat prosentase penerimaan pajak reklame Kota Palembang bahwa pada tahun 2016/2017 dengan tahun 2018/2019 mengalami kenaikan yang disebabkan banyaknya pembangunan-pembangunan konstruksi baru dan banyaknya visualisasi konten iklan dan mengakibatkan penerimaan pajak 
reklame mengalami peningkatan. Namun pada tahun 2017/2018 penerimaan pajak reklame menjadi menurun yaitu $-2,68 \%$ yang disebabkan oleh banyaknya konstruksi ilegal karena tidak adanya izin penyelenggaraan reklame dan sudah habis masa karena tidak diperpanjang sehingga pihak BPPD tidak dapat memungut pajak pada Wajib Pajak reklame. Akibatnya dari hal tersebut penerimaan pajak reklame pada tahun 2018 tidak mencapai target yang sudah ditetapkan. Untuk dapat mengetahui prosentase rata-rata tingkat kenaikan pajak reklame yang akan digunakan untuk menghitung potensi pajak reklame adalah sebagai berikut:

$$
\mathrm{Xr}=\frac{8,54 \%+-2,86 \%+12 \%}{3}=6 \%
$$

Rata-rata yang didapat dari tingkat kenaikan pajak reklame dari tahun 2016 sampai dengan tahun 2019 adalah sebesar 6\%. Hasil tersebut didapat dari perhitungan tahun $2016 / 2017$ sebesar $8,54 \%$, tahun $2017 / 2018$ sebesar $-2,68 \% \%$, dan tahun $2018 / 2019$ sebesar $12 \%$. Total tahun yang di perhitungkan adalah 3 tahun terhitung mulai dari tahun 2017 sampai dengan tahun 2019.

Berdasarkan teori yang diterapkan untuk mengetahui potensi penerimaan pajak reklame tahun yang akan datang atau tahun 2020 adalah sebagai berikut:

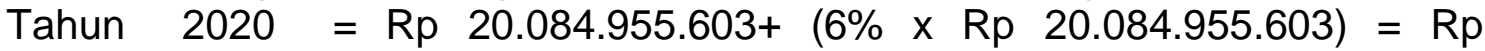
21.290.052.939

\section{Analisis Kontribusi Pajak Reklame dalam Meningkatkan Pendapatan Asli Daerah}

Kontribusi adalah uang iuran kepada perkumpulan dan sebagainya (Suharso dan Ana Retnoningsih, 2015: 264). Dalam Bahasa Inggris yaitu contribution yang artinya adalah menerima atau mengumpulkan sumbangan (John dan Hassan, 2007: 144). Kontribusi dapat berupa materi atau suatu tindakan. Dalam ekonomi kontribusi merupakan segala sesuatu yang diberikan untuk pihak lain dalam rangka tujuan bersama

Berdasarkan teori yang diterapkan kontribusi pajak reklame adalah sumbangan yang diberikan wajib pajak reklame terhadap besarnya PAD dengan rumus sebagai berikut :

\section{Rumusan Kontribusi Pajak Reklame :}

$\frac{\text { Jumlah Realisasi Pajak Reklame }}{\text { Jumlah Realisasi PAD }} \times 100 \%$

Tabel Kriteria Penggolongan Kontribusi

\begin{tabular}{|c|c|}
\hline Nilai Kontribusi & Kriteria \\
\hline $0,00 \%-10 \%$ & Sangat kurang \\
\hline $10,10 \%-20 \%$ & Kurang \\
\hline $20,10 \%-30 \%$ & Sedang \\
\hline $30,10 \%-40 \%$ & Cukup Baik \\
\hline $40,10 \%-50 \%$ & Baik \\
\hline$>50 \%$ & Sangat Baik \\
\hline
\end{tabular}

Sumber:Depdagri, Kepmendagri No. 690.900.327 Tahun 1996 
Tabel Rasio Kontribusi Pajak Reklame Terhadap PAD Kota Palembang

\begin{tabular}{|c|c|r|r|c|}
\hline Tahun & $\begin{array}{c}\text { Realiasasi Pajak } \\
\text { Reklame (Rp) }\end{array}$ & Realisasi PAD (Rp) & $\%$ & $\begin{array}{c}\text { Kriteria } \\
\text { Kontribusi }\end{array}$ \\
\hline 2016 & 16.567 .211 .469 & 781.346 .935 .715 & 2,12 & Sangat kurang \\
\hline 2017 & 18.113 .700 .816 & 1.091 .704 .605 .854 & 1,66 & Sangat kurang \\
\hline 2018 & 17.641 .773 .173 & 953.257 .612 .127 & 1,85 & Sangat kurang \\
\hline 2019 & 20.084 .955 .603 & 1.081 .514 .950 .141 & 1,86 & Sangat kurang \\
\hline
\end{tabular}

Sumber: Penulis, 2020.

Tabel diatas menunjukan bahwa tingkat rasio kontribusi pajak reklame dalam meningkatkan Pendapatan Asli Daerah Kota Palembang berada pada kriteria sangat kurang berkontribusi. Rasio kontribusi pajak reklame terhadap PAD Kota Palembang rata-rata berada pada rasio $\leq 10 \%$.

Pada tahun 2016 rasio kontribusi pajak reklame terhadap PAD Kota Palembang berada pada angka 2,12\%, angka tersebut menunjukan masih sangat kurangnya kontribusi pajak reklame terhadap PAD Kota Palembang. Pada tahun 2017 rasio kontribusi pajak reklame yang diberikan kepada Pendapatan Asli Daerah Kota Palembang berada pada angka 1,66\%, angka tersebut menunjukan masih sangat kurangnya kontribusi pajak reklame terhadap PAD Kota Palembang meskipun nilai kontribusi pajak reklame pada tahun 2019 meningkat dari tahun sebelumnya.

Tahun 2019 rasio kontribusi pajak reklame berada pada angka 1,86\% yang pada tahun 2018 berada pada angka 1,85\%, meskipun pada angka presentase mengalami peningkatan sebesar $0,01 \%$ namun untuk kriteria kontribusi masih sangat kurang berkontribusi.

Tahun 2017 rasio kontribusi pajak reklame terhadap PAD Kota Palembang berada pada angka 1,66\%, rasio kontribusi tersebut menurun dari beberapa tahun sebelumnya, hal ini pun menunjukan masih sangat kurangnya kontribusi pajak reklame terhadap PAD Kota Palembang, dan tahun 2019 rasio kontribusi pajak reklame sedikit mengalami peningkatan yaitu 1,86\%. Meskipun begitu kontribusi pajak reklame terhadap PAD Kota Palembang masih sangat kurang berkontribusi

\section{E. KESIMPULAN DAN SARAN \\ 1) KESIMPULAN} berikut:

Berdasarkan hasil penelitian dan pembahasan, dapat disimpulkan sebagai

a) Pajak reklame mempunyai potensi dalam meningkatkan Pendapatan Asli Daerah Kota Palembang yang akan di dapat pada tahun 2020 adalah sebesar Rp 21.290.052.939.

b) Kontribusi yang diberikan pajak reklame terhadap Pendapatan Asli Daerah pada Badan Pengelolaan Pajak Daerah (BPPD) Kota Palembang masih tergolong "sangat kurang" karena rasio kontribusi yang diberikan pada tahun 2016 sampai dengan 2019 rata-rata kurang dari 10\%. Rasio kontribusi yang diberikan pada tahun 2016 sebesar $2,12 \%$, pada tahun 2017 sebesar $1,66 \%$, pada tahun 2018 sebesar 1,85\%, dan pada tahun 2019 sebesar 1,86\%.

\section{2) SARAN}

Berdasarkan kesimpulan, penulis memberikan saran sebagai berikut:

a) Sebaiknya Badan Pengelolaan Pajak Daerah (BPPD) Kota Palembang perlu melakukan pendataan secara rutin terhadap objek pajak reklame yang baru dan yang sudah ada sehingga dapat diketahui potensi-potensi yang sebenarnya. 
b) Sebaiknya Badan Pengelolaan Pajak Daerah (BPPD) Kota Palembang bertindak tegas dengan Wajib Pajak yang menunggak membayar pajak, terutama pajak reklame namun masih menyelenggarakan reklame. Agar meningkatkan penerimaan pajak yang akan berdampak positif pada kontribusi pajak dalam meningkatkan Pendapatan Asli Daerah.

c) Sebaiknya Badan Pengelolaan Pajak Daerah (BPPD) Kota Palembang lebih gencar dalam mengadakan penyuluhan/sosialisasi kepada Wajib Pajak agar dapat melaksanakan kewajiban perpajakannya secara baik dan benar.

\section{DAFTAR PUSTAKA}

John, M. Echols dan Hassan Shadili. (2007). Kamus Inggris Indonesia. Jakarta: PT Gramedia.

Mardiasmo. (2018). Perpajakan. Edisi Terbaru. Yogyakarta: CV Andi Offset.

Pekei, Beni. (2016). Konsep dan Analisis Efektivitas Pengelolaan Keuangan Daerah di Era Otonomi. Jakarta: Taushia.

Peraturan Pemerintah Provinsi Daerah Khusus lbukota Jakarta. (2013). Keputusan Nomor 376 Tahun 2013 tentang Penetapan Formula Baku Perhitungan Potensi dan Rencana Penerimaan.

Peraturan Daerah Kota Palembang Nomor 14 Tahun 2010 tentang Pajak Reklame.

Peraturan Walikota Palembang Nomor 18 Tahun 2011 tentang Persyaratan, Mekanisme dan Prosedur Tetap Pemungutan Pajak Reklame.

Republik Indonesia. (2009). Undang-Undang Nomor 16 Tahun 2009 tentang Ketentuan Umum dan Tata Cara Perpajakan

Republik Indonesia. (2009). Undang-Undang Nomor 28 Tahun 2009 tentang Pajak Daerah dan Retribusi Daerah.

Republik Indonesia. (2004). Undang-Undang Nomor 32 Tahun 2004 tentang Pemerintah Daerah.

Republik Indonesia. (2000). Undang-Undang Nomor 34 Tahun 2000 tentang Pajak Daerah dan Retribusi Daerah.

Sugiyono. (2013). Metode Penelitian Kuantitatif Kualitatif dan R\&D. Alfabeta. Bandung.

Sugiyono. (2017). Metode Penelitian Kuantitatif Kualitatif dan R\&D. Alfabeta. Bandung.

Suharso dan Retnoningsih. (2015). Kamus Besar Bahasa Indonesia. Semarang: Widya Karya. 